\title{
Measurements of Environmental Radon Activity Concentration Outdoors in Bosnia and Hercegovina
}

\author{
Alma Damjanovic ${ }^{1}$, Jasmin Adrovic ${ }^{2}$, Zejnil Tresnjo ${ }^{3}$ and Feriz Adrovic ${ }^{2 *}$ \\ 1. The International School of The Hague, 2505 CA 2505 CA The Hague, The Netherlands \\ 2. University of Tuzla, Faculty of Natural Sciences and Mathematics, Univerzitetska 4, Tuzla, Bosnia and Herzegovina \\ 3. University Dzemal Bijedic of Mostar, Sjeverni logor bb, 88104 Mostar, Bosnia and Herzegovina
}

\begin{abstract}
Radon is a unique natural element because it is an inert gas and at the same time radioactive in all of its isotopes. It is known fact that exposure of the population to high concentrations of radon gas, leads to irradiation of primarily respiratory organs, which can cause lung cancer. For reliable prospecting of radon activity concentration in the living environment, the first input parameter is the concentration of outdoor radon in the air. This paper presents the results of a three-year research of radon activity concentration in the air of Bosnia and Herzegovina. At the measurement locations were registered daily and seasonal variations of the outdoor radon concentrations, whose average values were in the range of $15-38 \mathrm{~Bq} / \mathrm{m}^{3}$. They were measured with Alpha GUARD PQ 2000 radon portable measuring system (Genitron Instruments - Frankfurt).
\end{abstract}

Key words: Radon activity concentration, outdoor exposures, Bosnia and Herzegovina.

\section{Introduction}

One of the middle members of each natural series is the isotope of the noble gas radon: ${ }^{222} \mathrm{Rn},{ }^{220} \mathrm{Rn}$ and ${ }^{219} \mathrm{Rn}$ with the disintegration half-time of 3825 days, $55.6 \mathrm{~s}$ and $3.96 \mathrm{~s}$ respectively. Their immediate predecessors are radium isotopes which decompose into radon by $\alpha$-decay. Because of the very short half-life, as well as for the concentrations ratio ${ }^{235} \mathrm{U} /{ }^{238} \mathrm{U}$ in the nature, which is 0.00719 , the isotope ${ }^{219} \mathrm{Rn}$ can be ignored, while the isotope ${ }^{220} \mathrm{Rn}$ is of less importance due of its short half-life [1].

Because of the longest lifetime and isotopic abundance, the greatest importance of the natural isotopes of radon has ${ }^{222} \mathrm{Rn}$ and the term radon will refer to this isotope. In its decay series, radon gas over its short-lived decay progeny is transformed into stable lead ${ }^{206} \mathrm{~Pb}$, emitting 5 alpha particles of energy up to $7.7 \mathrm{MeV}$, beta radiation energy up to $2.8 \mathrm{MeV}$ and gamma-ray photon energy up to $2.4 \mathrm{MeV}$ [2].

*Corresponding author: Feriz Adrovic, full professor, research field: nuclear physics.
The concentration of radon in the air is variable and depends on a number of meteorological parameters. Due to the relatively long half-life (3.82 days), radon can stay relatively long in the atmosphere before it decays.

So it takes part in the turbulent transfer through the atmosphere and can reach to its higher layers, and travel long distances. Also, seasonal changes in meteorological conditions affect the variation of radon concentration in air, as well as the concentration of natural radioactivity of air in general.

The degradation products of radon and thoron in most cases are positively charged, from $80 \%$ to $85 \%$ of them, and are chemically active [2]. They interact with negative ions present in the atmosphere and in the process of exchanging charges there occurs their attachment to natural aerosols. This is the origin of naturally occurring radioactive aerosols. Increased relative humidity creates favorable conditions for increased condensation of water vapor and sorption of radioactive decay products as emanation of the particles of water vapor. The resulting active aerosols 
deposit under the influence of gravitational forces on the surface of the earth, where they remain on the vegetation, and easily penetrate into the soil.

Land contains different concentrations of uranium, which also leads to the release of certain amounts of radon from the soil. Radon reaches the atmosphere by diffusion through the pores and cavities in the soil, binding to the air or water [2]. For a given concentration of radon in the soil, the concentration of this gas that emanates in the atmosphere depends on the permeability of the soil (if the soil is dry, wet, frozen or covered with snow) and meteorological conditions (soil temperature and air temperature, atmospheric pressure, wind speed and direction of blowing). Concentration of outdoor radon rapidly decreases with altitude.

Ecological area of B \& H is a complex ecosystem, with different geological composition of rocks, vegetation cover, the area in which are manifested different intensities of turbulence in atmospheric pressure, temperature, humidity, which interact with each other including a variety of geochemical processes, which may be due to natural or anthropogenic influence.

Measurement of the activity concentration of radon outdoors were conducted at 92 measurement locations throughout Bosnia and Herzegovina (Fig. 1)

Reliable measuring of the concentration of outdoor radon requires special conditions, primarily silence of winds. It was one of the reasons of frequent measurements postponed because weather conditions sometimes did not allow continuous work. Radon gas is seven times heavier than air, and above ground it is present only in places where its exhalation is enabled. When radon reaches a height of about $1 \mathrm{~m}$ above the ground, its dispersion is determined by factors of

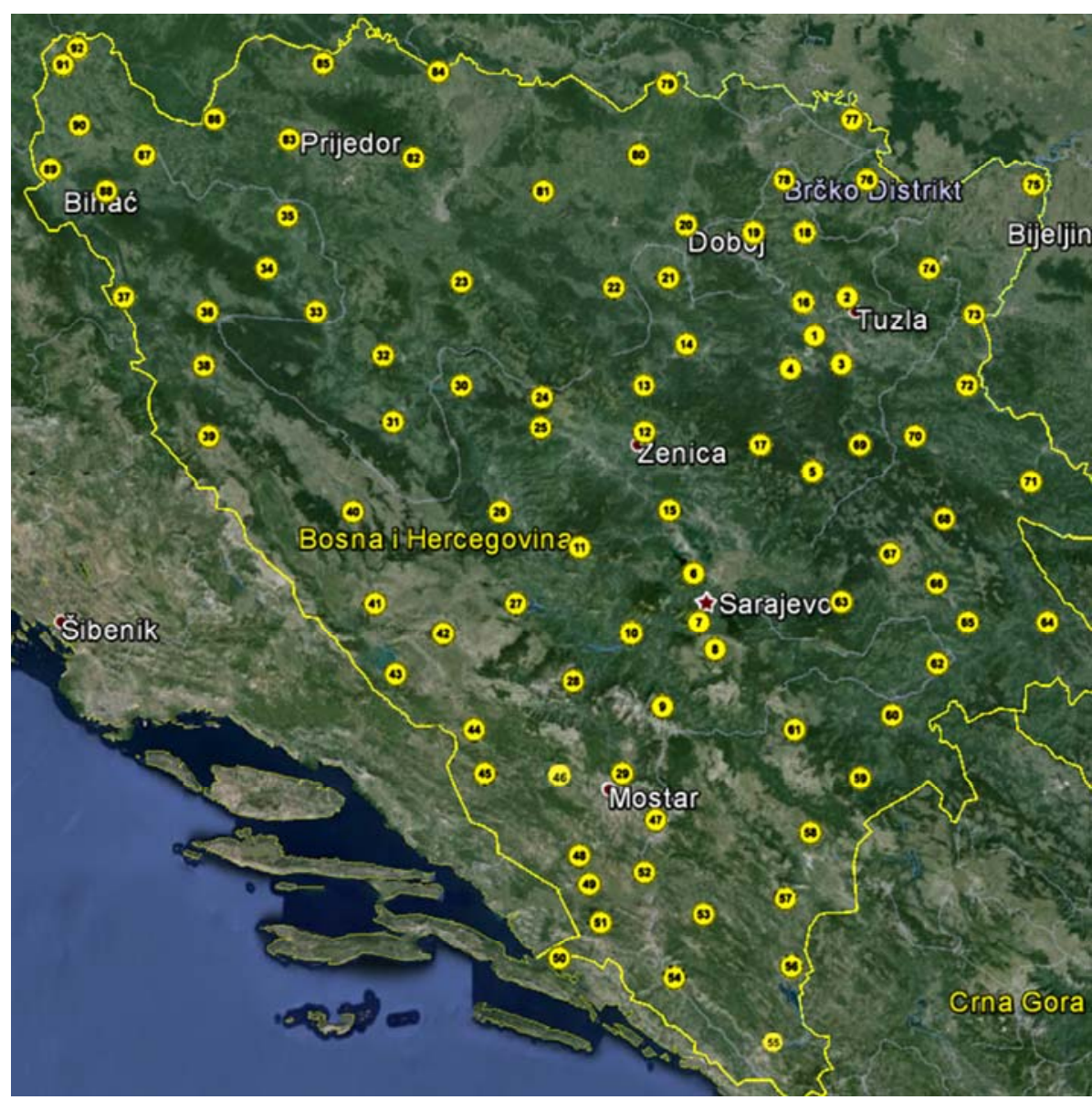

Fig. 1 Positions of measurement locations in the territory of B \& $\mathbf{H}$. 


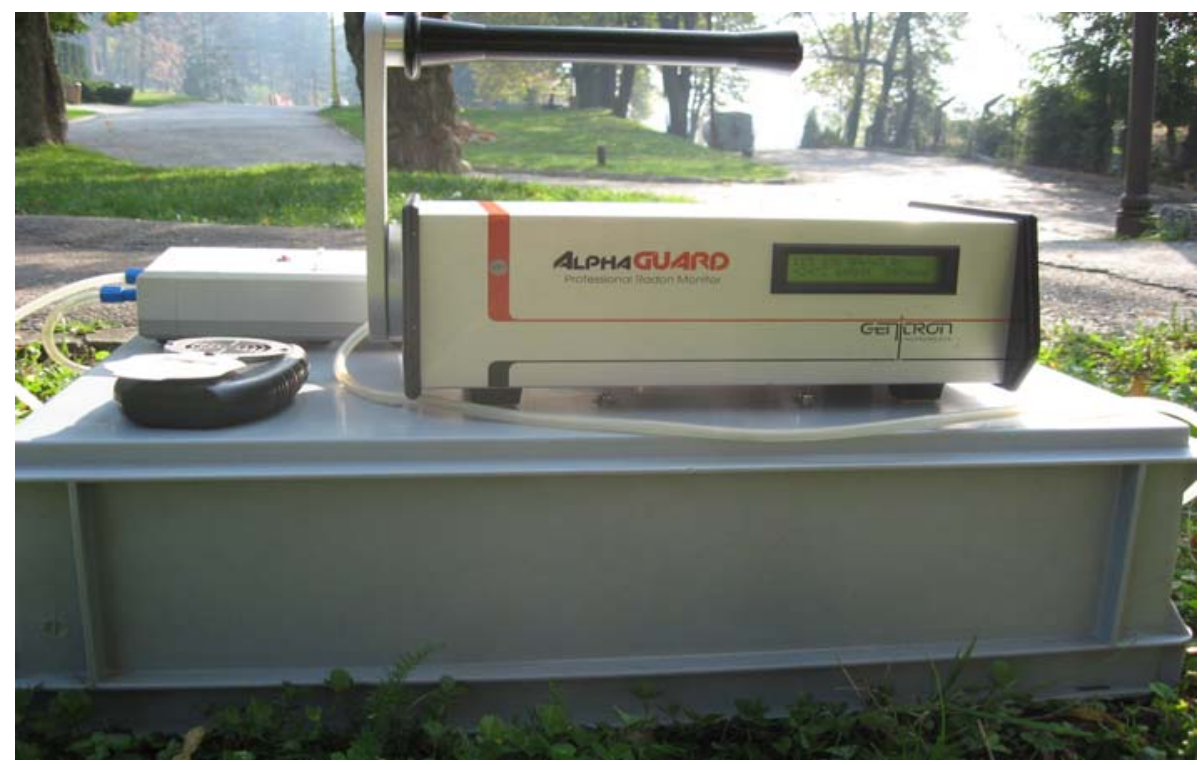

Fig. 2 AlphaGuard PQ 2000 PRO which was used for the research.

atmospheric stability.

\section{Material and Methods}

LDDRP (Laboratory for detection, dosimetry and radiation protection) at the Faculty of Sciences and Mathematics, University of Tuzla, Bosnia and Herzegovina, since 2004 has been engaged in measuring radon concentrations in all ambient environments, using different methods and modern measuring systems.

For the purpose of these studies, for measuring of radon activity concentration was used an AlphaGuard PQ 2000 PRO (Genitron Instruments, Frankfurt, Germany) [3].

Alpha Guard is an instrument used for permanent monitoring of radon concentration levels in the industry facilities or in air (Fig. 2). Measuring range of this system for concentration of radon activity is from $2 \sim 2 \times 10^{6} \mathrm{~Bq} / \mathrm{m}^{3}$, while the temperature range is from $-10{ }^{\circ} \mathrm{C}$ to $50{ }^{\circ} \mathrm{C}$. Calibration error for ${ }^{222} \mathrm{Rn}$ is $3 \%$. The cylindrical ionization chamber of the AlphaGuard device has the active volume of $0.56 \mathrm{dm}^{3}$. The basic configurations of this sistem are AlphaGuard, Radon Monitor and AlphaExpert software.

The measuring system Alpha GUARD PQ 2000, was installed to $1-1.5 \mathrm{~m}$ above the ground. All measurements of radon concentrations in air with AlphaGUARD PQ 2000 PRO were conducted in the measuring cycle of 5 and $10 \mathrm{~min}$. In this way, we obtained output of 5 and 10 min values of the activity concentration of radon, which is very essential for the screening of radon.

During the intense winds, measurements were interrupted, because in such circumstances, the registered values of concentrations of outdoor radon are of little importance. In other words, due to the relatively long half-life (3.82 days), radon carried by turbulent currents can cross large distances, so that the measurements in such conditions would be very unreliable.

\section{Results and Discussion}

Measurements of the activity concentration of outdoor radon were conducted at 92 sites. Time intervals of the measurements were in the range $3 \sim 6$ $\mathrm{h}$, and in some locations even longer, depending on the meteorological conditions in the field. At some locations, where the weather conditions (intense winds) changed during the measurement, the measurement was done at intervals.

Table 1 shows the mean activity concentration of outdoor radon at 92 measuring locations. 
Table 1 Radon activity concentration measured with AlphaGuard.

\begin{tabular}{|c|c|c|c|c|c|c|c|c|c|}
\hline \multirow{2}{*}{ No. } & \multirow{2}{*}{ Location } & \multicolumn{3}{|c|}{$\mathrm{RAC}\left[\mathrm{Bq} / \mathrm{m}^{3}\right]$} & \multirow{2}{*}{ No. } & \multirow{2}{*}{ Location } & \multicolumn{3}{|c|}{$\mathrm{RAC}\left[\mathrm{Bq} / \mathrm{m}^{3}\right]$} \\
\hline & & Average & Min. & Max. & & & Average & Min. & Max. \\
\hline 1 & Jezero Modrac & 18 & 4 & 38 & 47 & Blagaj & 18 & 1 & 43 \\
\hline 2 & Tuzla & 27 & 7 & 65 & 48 & Međugorje & 20 & 5 & 44 \\
\hline 3 & Živinice & 23 & 8 & 77 & 49 & Čapljina & 19 & 3 & 35 \\
\hline 4 & Banovići & 22 & 4 & 63 & 50 & Neum & 17 & 4 & 39 \\
\hline 5 & Olovo-Bakići & 38 & 15 & 85 & 51 & Huntovo blato & 18 & 3 & 43 \\
\hline 6 & Sarajevo-K. glava & 25 & 8 & 59 & 52 & Stolac & 15 & 3 & 44 \\
\hline 7 & Igman-Malo Polje & 26 & 9 & 48 & 53 & Ljubinje & 25 & 8 & 69 \\
\hline 8 & Bjelašnica-B. Do & 25 & 4 & 65 & 54 & Popovo polje. & 27 & 9 & 65 \\
\hline 9 & Boračko jezero & 22 & 7 & 60 & 55 & Trebinje & 18 & 1 & 60 \\
\hline 10 & Ivan-Sedlo & 18 & 4 & 43 & 56 & Bileće & 19 & 5 & 48 \\
\hline 11 & Fojnica-park & 26 & 8 & 60 & 57 & Gacko & 35 & 13 & 79 \\
\hline 12 & Zenica-K.park & 28 & 4 & 85 & 58 & Čemerno & 30 & 11 & 70 \\
\hline 13 & Nemila & 19 & 5 & 49 & 59 & Tjentište & 24 & 7 & 67 \\
\hline 14 & Zavidovići & 20 & 6 & 43 & 60 & Foča & 22 & 8 & 55 \\
\hline 15 & Visoko-pir. Sunca & 19 & 4 & 54 & 61 & Kalinovik & 31 & 9 & 66 \\
\hline 16 & Lukavac & 32 & 14 & 77 & 62 & Goražde & 19 & 5 & 61 \\
\hline 17 & Vareš & 27 & 6 & 69 & 63 & Pale & 20 & 3 & 51 \\
\hline 18 & Srebrenik & 22 & 8 & 55 & 64 & Višegrad & 18 & 6 & 54 \\
\hline 19 & Gračanica & 23 & 2 & 51 & 65 & Rogatica & 20 & 7 & 62 \\
\hline 20 & Doboj & 23 & 7 & 60 & 66 & Podromanija & 22 & 5 & 67 \\
\hline 21 & Tešanj & 26 & 4 & 57 & 67 & Sokolac & 20 & 6 & 56 \\
\hline 22 & Teslić & 25 & 9 & 62 & 68 & Han Pijesak & 24 & 8 & 53 \\
\hline 23 & Kotor Varoš & 22 & 1 & 58 & 69 & Kladanj & 25 & 4 & 56 \\
\hline 24 & Vlašić-Babanovac & 24 & 5 & 47 & 70 & Tišča & 23 & 5 & 50 \\
\hline 25 & Travnik & 23 & 6 & 45 & 71 & Srebrenica & 21 & 6 & 51 \\
\hline 26 & Bugojno & 21 & 8 & 54 & 72 & Zvornik & 20 & 7 & 44 \\
\hline 27 & Ramsko jezero & 22 & 3 & 47 & 73 & Kozluk & 26 & 9 & 67 \\
\hline 28 & Jablanica & 19 & 2 & 50 & 74 & Ugljevik & 37 & 8 & 86 \\
\hline 29 & Mostar & 20 & 6 & 48 & 75 & Dvorovi & 23 & 6 & 50 \\
\hline 30 & Jajce & 25 & 4 & 43 & 76 & Brčko & 20 & 5 & 52 \\
\hline 31 & Šipovo & 21 & 1 & 53 & 77 & Orašje & 22 & 5 & 54 \\
\hline 32 & Mrkonjić Grad & 24 & 7 & 59 & 78 & Gradačac & 27 & 3 & 66 \\
\hline 33 & Ključ & 26 & 6 & 44 & 79 & Bosanski Brod & 19 & 4 & 55 \\
\hline 34 & Sanica & 18 & 6 & 42 & 80 & Derventa & 24 & 7 & 49 \\
\hline 35 & Sanski Most & 19 & 3 & 48 & 81 & Prnjavor & 31 & 6 & 67 \\
\hline 36 & Bosanski Petrovac & 19 & 8 & 43 & 82 & Potkozarje & 25 & 6 & 54 \\
\hline 37 & Kulen Vakuf & 17 & 4 & 38 & 83 & Prijedor & 24 & 5 & 51 \\
\hline 38 & Drvar & 19 & 6 & 51 & 84 & Gradiška & 19 & 3 & 54 \\
\hline 39 & Bosansko Grahovo & 22 & 6 & 53 & 85 & Bosanska Dubica & 21 & 3 & 48 \\
\hline 40 & Glamoč & 29 & 7 & 84 & 86 & Novi Grad & 22 & 7 & 55 \\
\hline 41 & Livno & 33 & 12 & 70 & 87 & Bosanska Krupa & 29 & 7 & 73 \\
\hline 42 & Tomislavgrad & 22 & 5 & 54 & 88 & Bihać & 23 & 4 & 58 \\
\hline 43 & Buško jezero & 20 & 8 & 62 & 89 & Izarčić & 20 & 6 & 51 \\
\hline 44 & Posušje & 19 & 5 & 56 & 90 & Cazin & 18 & 2 & 45 \\
\hline 45 & Grude & 18 & 4 & 42 & 91 & Velika Kladuša & 21 & 2 & 57 \\
\hline 46 & Široki Brijeg & 19 & 7 & 40 & 92 & Ponikve & 24 & 6 & 63 \\
\hline
\end{tabular}


Mean values of the activity concentration of radon in air on the studied sites, were in the range of 15 to $38 \mathrm{~Bq} / \mathrm{m}^{3}$. The highest mean value was measured at the site No. 5, Olovo, $38 \mathrm{~Bq} / \mathrm{m}^{3}$, where the maximum activity concentration of radon during the measurement was $85 \mathrm{~Bq} / \mathrm{m}^{3}$. This locality is an area without industrial plants, real mountain beauty, ecologically preserved, but that does not mean that the radiological levels are ideal. The increased concentration of radon in this area, which was also observed in previous studies, may be due to the geological substrate, underground streams and fissures, or deposits of ores and rocks with increased uranium content.

The mean activity concentration of radon outdoors, which were above $30 \mathrm{~Bq} / \mathrm{m}^{3}$, were detected in the investigated localities: No. 81 - Prnjavor, $31 \mathrm{~Bq} / \mathrm{m}^{3}$, No. 16 - Lukavac, $32 \mathrm{~Bq} / \mathrm{m}^{3}$, No. 41 - Livno, $33 \mathrm{~Bq} / \mathrm{m}^{3}$, No. 57 - Gacko, $35 \mathrm{~Bq} / \mathrm{m}^{3}$ and No. 74-Ugljevik, 37 $\mathrm{Bq} / \mathrm{m}^{3}$. On most sites studied, the mean activity concentrations of radon were above the average values in the world, which vary in the range from 10 to 20 $\mathrm{Bq} / \mathrm{m}^{3}$.

For some explored sites, increased levels of radon are understandable, because they are the points of strong thermal power facilities, such as Tuzla, Ugljevik, Gacko and industrial cities of Lukavac and Zenica. The increase in the level of radon in these locations is due to technological processing of coal and its combustion in thermal power plants, as well as the production of coke and other raw materials. Of course, we have to take into account individual heating places in the winter, and especially the traffic with high frequency. For site No. 41- Livno, the cause of increased activity concentration of radon is coal with increased content of uranium.

A special case of high radon concentration is the area Slana Banja in Tuzla. At this location we detected high levels of exhaled radon gas a few years ago [8]. On this site, recorded were the levels of radon in the course of $24 \mathrm{~h}$ (Fig.4). The maximum value of the activity concentration of radon during this time period of measurement was $464 \mathrm{~Bq} / \mathrm{m}^{3}$, and the measured mean value of $230 \mathrm{~Bq} / \mathrm{m}^{3}$.

This extreme level of outdoor radon for now is a scientific enigma, which is interesting from geological, seizmic and health aspects.

On the basis of the obtained values of the activity concentration of outdoor radon in air, an assessment of

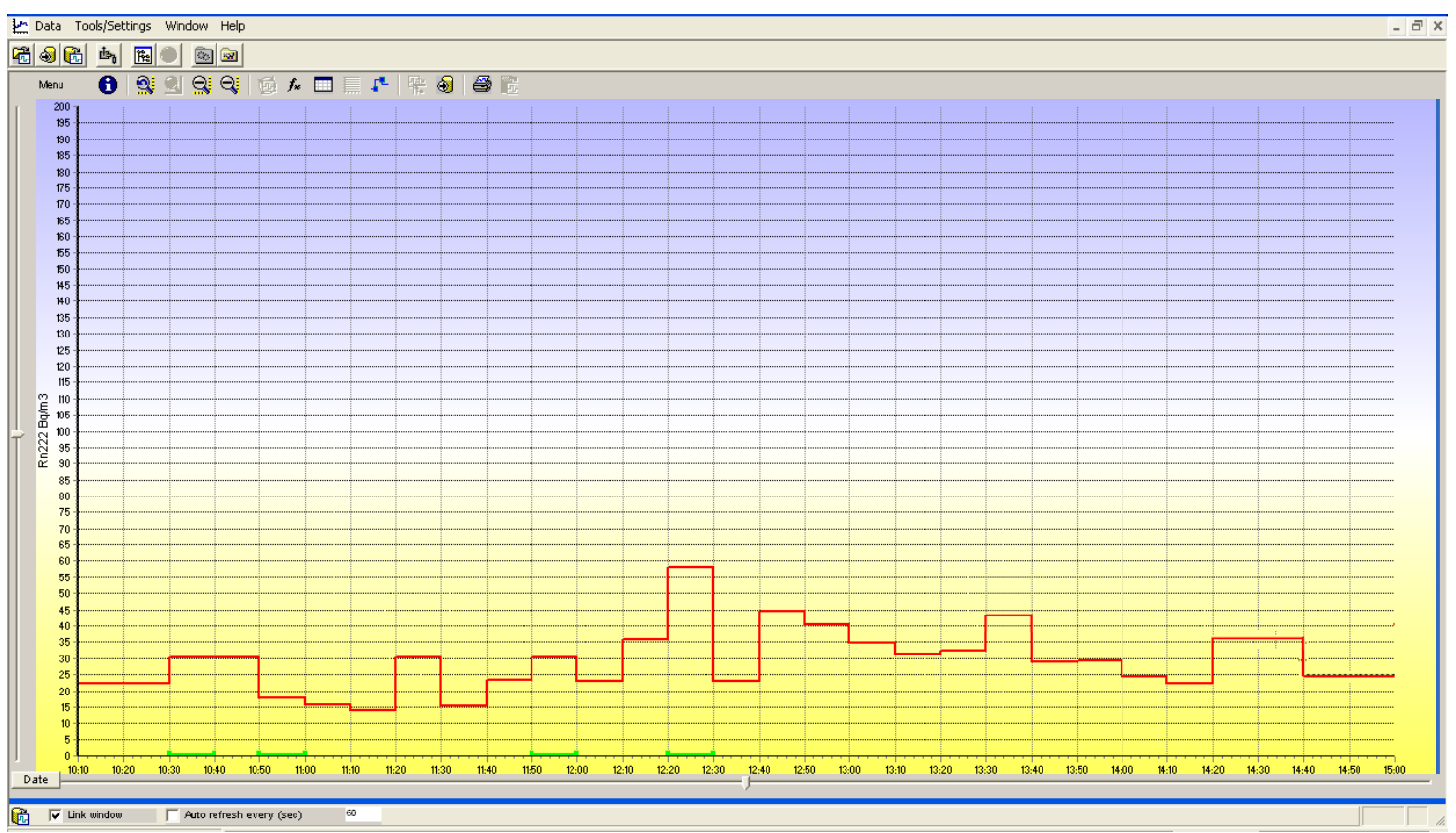

Fig. 3 The value of measured radon activity concentration at the locality No. 16-Lukavac. 


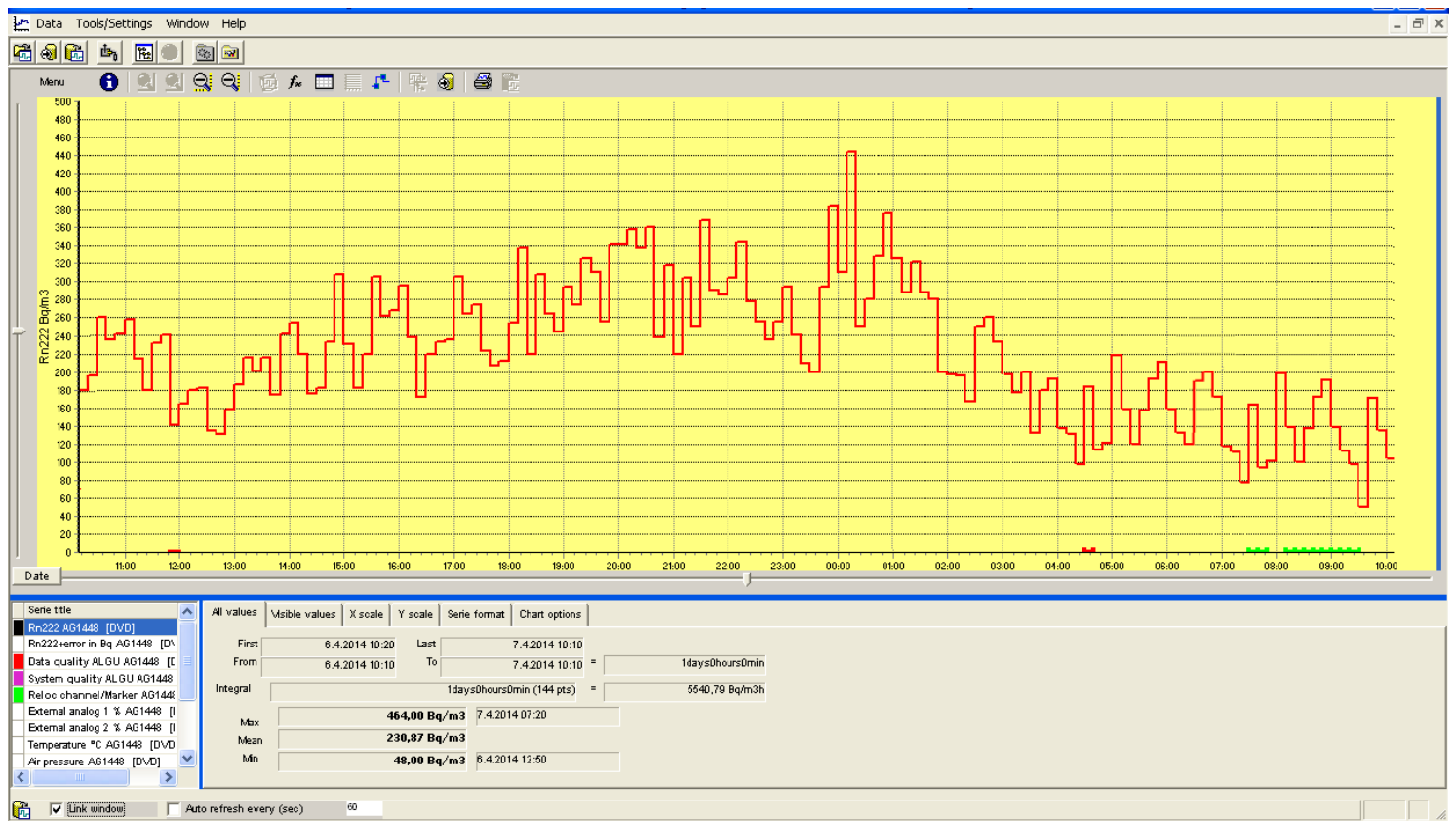

Fig. 4 The value of measured radon activity concentration at the locality No. 2-Slana Banja Tuzla.

Table 2 The estimated annual effective dose received by the population through inhalation of radon outdoors.

\begin{tabular}{|c|c|c|c|c|c|}
\hline No. & Location & $H_{\text {out }}(\mathrm{mSv})$ & No. & Location & $H_{\text {out }}(\mathrm{mSv})$ \\
\hline 1 & Jezero Modrac & 0.170 & 47 & Blagaj & 0.170 \\
\hline 2 & Tuzla & 0.236 & 48 & Međugorje & 0.189 \\
\hline 3 & Živinice & 0.217 & 49 & Čapljina & 0.179 \\
\hline 4 & Banovići & 0,208 & 50 & Neum & 0.160 \\
\hline 5 & Olovo-Bakići & 0.359 & 51 & Huntovo blato & 0.170 \\
\hline 6 & Sarajevo-K. glava & 0.236 & 52 & Stolac & 0.141 \\
\hline 7 & Igman-Malo Polje & 0.245 & 53 & Ljubinje & 0.236 \\
\hline 8 & Bjelašnica-B. Do & 0.236 & 54 & Popovo polje. & 0.255 \\
\hline 9 & Boračko jezero & 0.208 & 55 & Trebinje & 0.170 \\
\hline 10 & Ivan-Sedlo & 0.170 & 56 & Bileće & 0.179 \\
\hline 11 & Fojnica-park & 0.245 & 57 & Gacko & 0.331 \\
\hline 12 & Zenica-K.park & 0.264 & 58 & Čemerno & 0.283 \\
\hline 13 & Nemila & 0.179 & 59 & Tjentište & 0.227 \\
\hline 14 & Zavidovići & 0.189 & 60 & Foča & 0.208 \\
\hline 15 & Visoko-pir. Sunca & 0.179 & 61 & Kalinovik & 0.293 \\
\hline 16 & Lukavac & 0.302 & 62 & Goražde & 0.179 \\
\hline 17 & Vareš & 0.255 & 63 & Pale & 0.189 \\
\hline 18 & Srebrenik & 0.208 & 64 & Višegrad & 0.170 \\
\hline 19 & Gračanica & 0.217 & 65 & Rogatica & 0.189 \\
\hline 20 & Doboj & 0.217 & 66 & Podromanija & 0.208 \\
\hline 21 & Tešanj & 0.245 & 67 & Sokolac & 0.189 \\
\hline 22 & Teslić & 0.236 & 68 & Han Pijesak & 0.227 \\
\hline 23 & Kotor Varoš & 0.208 & 69 & Kladanj & 0.236 \\
\hline 24 & Vlašić-Babanovac & 0.227 & 70 & Tišča & 0.217 \\
\hline 25 & Travnik & 0.217 & 71 & Srebrenica & 0.198 \\
\hline 26 & Bugojno & 0.198 & 72 & Zvornik & 0.189 \\
\hline 27 & Ramsko jezero & 0.208 & 73 & Kozluk & 0.245 \\
\hline
\end{tabular}




\begin{tabular}{|c|c|c|c|c|c|}
\hline No. & Location & Hout $(\mathrm{mSv})$ & No. & Location & Hout (mSv) \\
\hline 28 & Jablanica & 0.179 & 74 & Ugljevik & 0.350 \\
\hline 29 & Mostar & 0.189 & 75 & Dvorovi & 0.217 \\
\hline 30 & Jajce & 0.236 & 76 & Brčko & 0.189 \\
\hline 31 & Šipovo & 0.198 & 77 & Orašje & 0.208 \\
\hline 32 & Mrkonjić Grad & 0.227 & 78 & Gradačac & 0.255 \\
\hline 33 & Ključ & 0.245 & 79 & Bosanski Brod & 0.179 \\
\hline 34 & Sanica & 0.170 & 80 & Derventa & 0.227 \\
\hline 35 & Sanski Most & 0.179 & 81 & Prnjavor & 0.293 \\
\hline 36 & Bosanski Petrovac & 0.179 & 82 & Potkozarje & 0.236 \\
\hline 37 & Kulen Vakuf & 0.160 & 83 & Prijedor & 0.227 \\
\hline 38 & Drvar & 0.179 & 84 & Gradiška & 0.179 \\
\hline 39 & Bosansko Grahovo & 0.208 & 85 & Bosanska Dubica & 0.198 \\
\hline 40 & Glamoč & 0.274 & 86 & Novi Grad & 0.208 \\
\hline 41 & Livno & 0.312 & 87 & Bosanska Krupa & 0.274 \\
\hline 42 & Tomislavgrad & 0.208 & 88 & Bihać & 0.217 \\
\hline 43 & Buško jezero & 0.189 & 89 & Izarčić & 0.189 \\
\hline 44 & Posušje & 0.179 & 90 & Cazin & 0.170 \\
\hline 45 & Grude & 0.170 & 91 & Velika Kladuša & 0.198 \\
\hline 46 & Široki Brijeg & 0.179 & 92 & Ponikve & 0.227 \\
\hline
\end{tabular}

the annual effective dose received by the population due to inhalation of radon gas in the investigated area (Table 2) was made. To estimate the annual effective dose of radiation, which comes from the inhalation of radon outdoors, it is necessary to take into account a number of input parameters. It is assumed that the average length of stay in the open air is $20 \%$ of the time during the day. The conversion factor for radon radiation dose is $9 \mathrm{nSv}\left(\mathrm{Bq} \cdot \mathrm{h} \cdot \mathrm{m}^{-3}\right)^{-1}$, while the balance factor of radon outdoors is 0.6 [2]. Then the annual effective dose is calculated according to the formula:

$$
H_{\text {out }}=C_{R n} \cdot F_{\text {out }} \cdot t \cdot 0.2 \cdot D
$$

where, $H_{\text {out }}$ - the requested annual effective dose that comes from the inhalation of radon in outdoor space $(\mathrm{mSv}) ; C_{R n}-$ radon activity concentration in air $\left(\mathrm{Bq} / \mathrm{m}^{3}\right)$; $F_{\text {out }}=0.6$ - the balance factor of radon outdoors; $t-$ time, or the average number of hours per year $\mathrm{D}=9$ $\mathrm{nSv} /\left(\mathrm{Bq} \cdot \mathrm{h} \cdot \mathrm{m}^{-3}\right)$ - conversion factor dose for radon.

The estimated annual effective dose received by the population from inhalation of radon outdoors is in the range from 0.141 to $0.359 \mathrm{mSv}$. According to the UNSCEAR report (2000), at a radon activity concentration of $10 \mathrm{~Bq} / \mathrm{m}^{3}$, the annual effective dose due to inhalation of radon outdoor is $0.095 \mathrm{mSv}$.

\section{Conclusions}

Knowing the activity concentration of outdoor radon is of great importance for the levels of radon in residential and work areas. Based on the obtained results it can be concluded that at majority of the investigated locations the values of annual effective dose from inhalation of outdoor radon were above the average value for the world.

\section{References}

[1] Adrovic, F., Jakupi, B. and Vasić, P. 1995. "Measurements of Radon Concentration, Radiation Measurements." 25 (1): 643-4.

[2] UNSCEAR 2008 Report to the General Assembly Scientific Annexes, Sources and Effects of Ionizing Radiation. 2010. United Nations Scientific Committee on the Effects of Atomic Radiation, UN, New York.

[3] Alpha Guard PQ2000 Multiparameter Radon Monitor. 1998. User Manual, Genitron Instruments, Germany.

[4] Kasic, A., Hankic, E., Kasumovic, A. and Adrovic, F. 2013. "Levels of Radon Activity Concentration in Thermal Waters of Bosnia and Herzegovina." Journal of Materials Science and Engineering B 3 (8): 539-44.

[5] Durrani, S. A. and R. Ilic, R. 1997. Measurements by 
Etched Track Detectors: Applications in Radiation Protection, Earth Sciences and the Environment, World Scientific, Singapore.

[6] Alpha Guard PQ2000 Multiparameter Radon Monitor. 1998. User Manual, Genitron Instruments, Germany.

[7] Vidic, A., Ilic, D., Deljkic, D., and Adrovic, F. 2011.
"Exposure of Workers in Tusnica Coal Mine." Radiation Protection Dosimetry 144 (1-4): 672-74.

[8] Kasic, A., Hankic, E., Kasumovic, A. and Adrovic, F. 2013. "Levels of Radon Activity Concentration in Thermal Waters of Bosnia and Herzegovina." Journal of Materials Science and Engineering B 3 (8): 539-44. 